\title{
Investigation of the association between mitochondrial DNA and $p 53$ gene mutations in transitional cell carcinoma of the bladder
}

\author{
TUBA AVCILAR ${ }^{1}$, DENIZ KIRAC ${ }^{2}$, DENIZ ERGEC ${ }^{1}$, GULSAH KOC $^{3}$, KORKUT ULUCAN $^{4}$, \\ ZEHRA KAYA $^{5}$, ELIF CIGDEM KASPAR ${ }^{6}$, LEVENT TURKERI ${ }^{7}$ and AHMET ILTER GUNEY ${ }^{1}$ \\ ${ }^{1}$ Department of Medical Genetics, Faculty of Medicine, Marmara University, Istanbul 34890; \\ ${ }^{2}$ Department of Medical Biology, Faculty of Medicine, Yeditepe University, Istanbul 34755; \\ ${ }^{3}$ Department of Medical Biology, Faculty of Medicine, Istanbul Aydın University, Istanbul 34295; \\ ${ }^{4}$ Department of Medical Biology and Genetics, Faculty of Dentistry, Marmara University, Istanbul 34854; \\ ${ }^{5}$ Department of Medical Biology, Faculty of Medicine, Yuzuncu Y1l University, Van 65080; \\ ${ }^{6}$ Department of Biostatistics, Faculty of Medicine, Yeditepe University, Istanbul 34755; \\ ${ }^{7}$ Department of Urology, Faculty of Medicine, Marmara University, Istanbul 34890, Turkey
}

Received July 7, 2015; Accepted April 29, 2016

DOI: $10.3892 / \mathrm{ol} .2016 .5000$

\begin{abstract}
Bladder carcinoma is the most common malignancy of the urinary tract. The major aim of the present study is to investigate the association between mitochondrial DNA (mtDNA) and $p 53$ gene mutations in bladder carcinoma. A total of 30 patients with transitional cell carcinoma and 27 controls were recruited for the study. Bladder cancer tissues were obtained by radical cystectomy or transurethral resection. Genomic DNA was extracted from peripheral blood. mtDNA and $p 53$ genes were amplified by polymerase chain reaction and sequenced directly. A total of 37 polymorphisms were identified, among which, 2 mutations were significant in the patient group, and 1 mutation was significant in the control group. Additionally, 5 different moderate positive correlations between mtDNA mutations and 3 different positive correlations between $p 53$ gene and mtDNA mutations were detected. The high incidence of mtDNA and p53 gene mutations in bladder cancer suggests that these genes could be important in carcinogenesis.
\end{abstract}

\section{Introduction}

Bladder cancer is one of the most common types of cancer in the Western male population (1). It is mainly classified into two types: Superficial bladder cancer (pTis, pTa and pT1), which does not invade into the muscle layer; and invasive bladder

Correspondence to: Dr Deniz Kıraç, Department of Medical Biology, Faculty of Medicine, Yeditepe University, Kayisdagi Street, 6th floor, Room 1,030, Kayışdağ1-Ataşehir, Istanbul 34755, Turkey E-mail: denizyat@hotmail.com

Key words: bladder carcinoma, mtDNA, p53, TCC cancer (pT2, pT3 and pT4), which invades through the muscle layer. These two cancer types exhibit different clinical behaviors, with superficial bladder cancers being generally low-grade (grade 1 or 2) tumors, the majority of which have a good prognosis; however, in 10-20\% of cases, cancer cells become more malignant. By contrast, invasive bladder cancers are high-grade (grade 3) tumors, which are very aggressive, as they develop and progress rapidly and metastasize in an early stage (2).

Almost half of all the bladder cancer cases diagnosed to date have been attributed to environmental carcinogens such as tobacco smoking. Genetic and epigenetic changes that drive cells into carcinogenesis have been linked to environmental and occupational exposures in non-smokers, and these constitute a significant proportion among non-smoker bladder cancer cases. Molecular studies are being currently conducted to measure the effects of inheritance that may be important in the epidemiology of bladder cancer (3).

The majority of bladder cancers are transitional cell carcinomas (TCCs), which originate from the cells lining the inside of the bladder. TCC of the bladder is the second most common malignancy of the genitourinary tract, and the second most common cause of mortality among all genitourinary tumors (4). TCC provides a good model for understanding the genetic basis of tumors, since the histological progression of this tumor is correlated with p53 gene mutations (5). p53 is a human tumor suppressor gene that codes for the p53 protein. p53 is a nuclear phosphoprotein that acts as a transcription factor and regulates cell cycle events such as cell arrest or apoptosis under different circumstances, including hypoxia, DNA damage and metabolic changes that alter cell activity (6). Regardless the type and stage of cancer, p53 has come to the forefront of research because it is commonly mutated in multiple human cancers (7), including bladder cancer (8). Mutations in the $p 53$ gene are usually located in functionally important regions that have been highly conserved over the 
evolution of species. These regions are located in exons 5-8 (codons 126-306) of the $p 53$ gene (8). In addition to $p 53$ mutations, mitochondrial DNA (mtDNA) is prone to mutations due to the absence of protective histone backbones and efficient repair mechanisms, as emerged in cancer research. Although several reports suggested the important role of mtDNA in different cancer types, very few publications have reported the detection of mtDNA mutations in bladder cancer (9-13). In addition, alterations in the $p 53$ gene and in mtDNA genes have been examined in a variety of solid tumors, but the number of studies focussing on bladder cancer are insufficient (14). Therefore, the aim of the present study is to identify the association between $p 53$ and mtDNA mutations in TTC of superficial bladder cancer.

\section{Materials and methods}

Clinical samples. Tissue specimens $(n=30)$ were collected by transurethral resection from patients diagnosed with TCC of the bladder who were treated at the Department of Urology, Faculty of Medicine, Marmara University (Istanbul, Turkey) from 1997 to 2010. All patients provided written informed consent prior to inclusion in the study. All tumors were staged and graded by pathology at Marmara University Hospital (Istanbul, Turkey). Following pathological evaluation for histological grade and stage, DNA extraction was performed from the snap-frozen samples. In addition, samples of normal bladder tissues $(n=27)$ were obtained during transurethral resection of the prostate and radical prostatectomy operations. The specimens were stored at $-80^{\circ} \mathrm{C}$ until DNA extraction. The demographic, tumoral and progression characteristics of the patients are summarized in Table I. The experimental protocol was approved by the ethical committee of Marmara University (MAR-AEK-09-2010-0055).

DNA extraction. Genomic DNA was extracted from tissues using a commercial kit (InViTek, Berlin, Germany), according to the manufacturer's protocol. The final DNA pellets were dissolved in double distilled water, and the DNA concentrations were measured by spectrophotometry. DNA samples were kept at $-20^{\circ} \mathrm{C}$ until use.

Polymerase chain reaction (PCR) amplification of mtDNA. For detection of mtDNA mutations, the reduced nicotinamide adenine dinucleotide dehydrogenase 1 (ND1), adenosinetriphosphatase 6 (ATPase6) and cytochrome b (Cytb) genes, and the D310 region, were amplified by PCR using 10-20 ng total DNA. Table II lists the sequences of primers specific for human mtDNA genes and the D310 region.

PCR amplifications of the ND1, ATPase 6 and Cytb genes were performed in a total volume of $50 \mu 1$ containing $50-100 \mathrm{ng}$ DNA template in $10 \mathrm{mM}$ Tris- $\mathrm{HCl}(\mathrm{pH} 8.0), 50 \mathrm{mM} \mathrm{KCl}$, $1.5 \mathrm{mM} \mathrm{MgCl}$, deoxynucleotides (dNTPs; $100 \mathrm{mM}$ each), 1.0 U Taq DNA polymerase and primers (12.5 pmol each). The conditions of PCR amplification were as follows: A denaturation step at $94^{\circ} \mathrm{C}$ for $5 \mathrm{~min}$, followed by 35 cycles at $94^{\circ} \mathrm{C}$ for $1 \mathrm{~min}$, annealing at $59^{\circ} \mathrm{C}$ for $1 \mathrm{~min}$, extension at $72^{\circ} \mathrm{C}$ for $1 \mathrm{~min}$, a final extension at $72^{\circ} \mathrm{C}$ for $5 \mathrm{~min}$ and stop at $4^{\circ} \mathrm{C}$. PCR amplifications for the D310 region were performed in a total volume of $50 \mu \mathrm{l}$ containing 50-100 ng DNA template in $10 \mathrm{mM}$
Table I. Demographic, tumoral and progression characteristics of patients.

\begin{tabular}{cccccc}
\hline $\begin{array}{c}\text { Patient } \\
\text { number }\end{array}$ & Gender & Stage & Grade & Recurrence & Progression \\
\hline 1 & Male & T1 & G2 & Absent & Absent \\
2 & Male & T1 & G3 & Absent & Absent \\
3 & Male & T1 & G2 & Present & Absent \\
4 & Female & T1 & G2 & Present & Absent \\
5 & Female & T1 & G2 & Present & Present \\
6 & Male & T1 & G2 & Present & Absent \\
7 & Female & Ta & G1 & Present & Absent \\
8 & Female & T1 & G1 & Present & Absent \\
9 & Male & T1 & G3 & Present & Present \\
10 & Male & Ta & G2 & Present & Present \\
11 & Female & T1 & G2 & Present & Absent \\
12 & Male & T1 & G2 & Absent & Absent \\
13 & Male & T1 & G2 & Present & Absent \\
14 & Female & T1 & G3 & Absent & Absent \\
15 & Male & Ta & G2 & Present & Absent \\
16 & Male & Ta & G1 & Present & Absent \\
17 & Male & T1 & G1 & Present & Absent \\
18 & Male & T1 & G2 & Present & Present \\
19 & Female & T1 & G1 & Present & Absent \\
20 & Male & T1 & G2 & Present & Present \\
21 & Female & T1 & G2 & Present & Absent \\
22 & Male & Ta & G2 & Present & Absent \\
23 & Female & T1 & G1 & Present & Present \\
24 & Male & Ta & G1 & Absent & Absent \\
25 & Male & Ta & G1 & Absent & Absent \\
26 & Male & T1 & G2 & Present & Absent \\
27 & Male & T1 & G2 & Present & Absent \\
28 & Male & Ta & G1 & Present & Absent \\
& Female & Ta & G1 & Present & Absent \\
\hline 0 & Male & Ta & Present & Present
\end{tabular}

Tris- $\mathrm{HCl}$ (pH 8.0), $50 \mathrm{mM} \mathrm{KCl}, 1.25 \mathrm{mM} \mathrm{MgCl} 2,100 \mathrm{mM}$ each of the different dNTPs, $1.0 \mathrm{U}$ Taq DNA polymerase and $10 \mathrm{pmol}$ each primer. The conditions of PCR amplification of the D310 region were as follows: A denaturation step at $95^{\circ} \mathrm{C}$ for $2 \mathrm{~min}$, followed by 35 cycles at $95^{\circ} \mathrm{C}$ for $30 \mathrm{sec}$, annealing at $60^{\circ} \mathrm{C}$ for $30 \mathrm{sec}$, extension at $72^{\circ} \mathrm{C}$ for $1 \mathrm{~min}$, a final extension at $72^{\circ} \mathrm{C}$ for 5 min and stop at $4^{\circ} \mathrm{C}$. All PCR products were fractionated by electrophoresis on a $2 \%$ agarose gel. The sizes of the fragments of the ND1, ATPase 6 and Cytb genes following amplification were 934, 675 and 1,064 bp respectively. The size of the fragment containing the D310 region was $109 \mathrm{bp}$.

PCR amplification of the p53 gene. Tumors were screened for mutations in the $p 53$ gene between exons 5 and 8, which encompass the DNA-binding domain of the encoded protein. Table II lists the primer sequences for the human $p 53$ gene between exons 5 and 8. Primers used for the amplification of exon 6 also amplified the end of intron 5. The sizes of the fragments obtained upon amplification were 205, 173, 149 and 157 bp for exons 5, 6, 
Table II. Sequences of the primers used for polymerase chain reaction analysis of mutations in human mtDNA genes and D310 region and in the human $p 53$ gene (exons 5-8).

\begin{tabular}{|c|c|}
\hline Genes & Primer sequence \\
\hline \multicolumn{2}{|l|}{ mtDNA } \\
\hline$N D 1$ & $\begin{array}{l}\text { Forward, 5'-CCAACCTCCTACTCCTCATTGT-3' } \\
\text { Reverse, 5'-TGATCAGGGTGAGCATCAAA-3' }\end{array}$ \\
\hline ATPase6 & $\begin{array}{l}\text { Forward, 5'-AACGAAAATCTGTTCGCTTCAT-3' } \\
\text { Reverse, 5'-ATGTGTTGTCGTGCAGGTAGAG-3' }\end{array}$ \\
\hline$C y t b$ & $\begin{array}{l}\text { Forward, 5'-TATCCGCCATCCCATACATT-3' } \\
\text { Reverse, 5'-GGTGATTCCTAGGGGGTTGT-3' }\end{array}$ \\
\hline D310 & $\begin{array}{l}\text { Forward,5'-ACAATTGAATGTCTGCACAGCCAC } \\
\text { Reverse, 5'-GGCAGAGATGTGTTTAAGTGCTG- }\end{array}$ \\
\hline \multicolumn{2}{|l|}{ p53, exon } \\
\hline 5 & $\begin{array}{l}\text { Forward, 5'-TCTTCCTACAGTACTCCCCT-3' } \\
\text { Reverse, 5'-AGCTGCTCACCATCGCTATC-3' }\end{array}$ \\
\hline 6 & $\begin{array}{l}\text { Forward, 5'-CCTCTGATTCCTCACTGATTGC-3' } \\
\text { Reverse, 5'-CTCCTCCCAGAGACCCCAG-3' }\end{array}$ \\
\hline 7 & $\begin{array}{l}\text { Forward, 5'-TCTCCTAGGTTGGCTCTGAC-3' } \\
\text { Reverse, 5'-CCAGTGTGCAGGGTGGCAAG-3' }\end{array}$ \\
\hline 8 & $\begin{array}{l}\text { Forward, 5'-TCCTGAGTAGTGGTAATCTA-3' } \\
\text { Reverse, 5'-GCTTGCTTACCTCGCTTAGT-3' }\end{array}$ \\
\hline
\end{tabular}

mtDNA, mitochondrial DNA; ND1, reduced nicotinamide adenine dinucleotide dehydrogenase 1; ATPase6, adenosinetriphosphatase 6; $\underline{\text { Cytb }}$. cytochrome $b$.

7 and 8 of the $p 53$ gene, respectively. PCR amplifications were performed in a total volume of 50 $\mu \mathrm{l}$ containing 50-100 ng DNA template in $10 \mathrm{mM}$ Tris- $\mathrm{HCl}(\mathrm{pH} 8.0), 50 \mathrm{mM} \mathrm{KCl}, 1.5 \mathrm{mM}$ $\mathrm{MgCl}_{2}$, dNTPs (100 mM each), $0.5 \mathrm{U}$ Taq DNA polymerase and 15 pmol each primer. For all exons, the PCR procedures were the same, with the exception of the annealing temperature. The conditions of PCR amplification were as follows: A denaturation step at $94^{\circ} \mathrm{C}$ for $5 \mathrm{~min}$, followed by 35 cycles at $94^{\circ} \mathrm{C}$ for $1 \mathrm{~min}$, extension at $72^{\circ} \mathrm{C}$ for $1 \mathrm{~min}$, a final extension at $72^{\circ} \mathrm{C}$ for $5 \mathrm{~min}$ and stop at $4^{\circ} \mathrm{C}$. Annealing temperatures and durations were $57^{\circ} \mathrm{C}$ for $1 \mathrm{~min}, 61^{\circ} \mathrm{C}$ for $1 \mathrm{~min}, 60^{\circ} \mathrm{C}$ for $1 \mathrm{~min}$ and $55^{\circ} \mathrm{C}$ for $1 \mathrm{~min}$, for exons 5, 6,7 and 8, respectively. All PCR products were fractionated by electrophoresis on a $2 \%$ agarose gel, and products exhibiting appropriate sizes were purified using a commercial kit (Roche Applied Science, Penzberg, Germany), according to the manufacturer's protocol.

Purification of PCR products and direct sequencing of $m t D N A$ and 553 gene regions. The purified PCR products were sequenced with an ABI PRISM 310 genetic analyzer (Applied Biosystems; Thermo Fisher Scientific, Inc., Waltham, MA, USA).

Statistical analysis. SPSS version 21.0 (IBM SPSS, Armonk, NY, USA) was used for statistical analysis. The $\chi^{2}$ and Fisher's exact tests were used to determine the association between patient and control groups for mtDNA and p53 mutations. The Bonferroni-corrected P-value was used to evaluate the statistical significancy. Additionally, the Spearman's rank correlation coefficient (r) test was used to evaluate the correlation between $m t D N A$ and $p 53$ mutations.

\section{Results}

DNA sequencing. The results of DNA sequencing demonstrated various point mutations in the mitochondrial genome of the human tumor samples. A total of 34 polymorphisms were identified in mtDNA genes, 15 of which cause amino acid substitutions. In addition, 3 novel polymorphisms were detected in the $p 53$ gene. The distribution of mutations/polymorphisms is summarized in Table III.

Comparision of mutations/polymorphisms between patient and control groups. The $\mathrm{A} 15607 \mathrm{G}$ polymorphism in the Cytb gene and the 12570-A insertion in the p53 gene were significantly higher in patients than in controls $(\mathrm{P}<0.05)$, whereas the $\mathrm{C} 12570 \mathrm{~A}$ heterozygote mutation was significantly higher in controls than in patients $(\mathrm{P}<0.05)$. Representative DNA sequencing chromatograms of various polymorphisms in the ATPase 6, Cytb and ND1 genes, and of novel polymorphisms in the p53 gene, are shown in Fig. 1, while representative chromatograms of the D310 region are shown in Fig. 2. The numbers and percentages of mutations in different stages, grades, progression and recurrence are shown in Table IV.

Comparision of mutations/polymorphisms according to tumor stage. A15607G polymorphism and 12570-A insertion were significant in patients at $\mathrm{T} 1$ stage $(\mathrm{P}<0.05)$.

Correlationresults. $\mathrm{P}<0.05$ and $\mathrm{r}=0.25-0.49$ indicateaweakpositive correlation between two mutations/polymorphisms, while $r>0.5$ and $r<0.5$ indicate a moderate positive and negative correlation, respectively, between two mutations/polymorphisms. 
Table III. mtDNA mutations identified in the D310 region and in the ATPase6, Cytb and ND1 genes.

\begin{tabular}{|c|c|c|c|c|c|c|}
\hline $\begin{array}{l}\text { Nucleotide } \\
\text { position }\end{array}$ & $\begin{array}{c}\text { Nucleotide } \\
\text { change }\end{array}$ & $\begin{array}{l}\text { Amino acid } \\
\text { change }\end{array}$ & $\begin{array}{c}\text { Mutation frequency } \\
\text { (\% of cases })\end{array}$ & $\begin{array}{c}\text { Mutation frequency } \\
\text { (\% of cases) }\end{array}$ & $\mathrm{P}$-value & $\begin{array}{l}\text { Reported in } \\
\text { Mitomap }^{\mathrm{b}} \text { and } \\
\text { other tumors }\end{array}$ \\
\hline
\end{tabular}

D310-ND1; $\mathrm{P}<0.05$ was considered to indicate a statistically significant difference

\begin{tabular}{lccccc}
\hline- & - & $1 / 30(3)$ & $0 / 27(0)$ & 1.000 & $\mathrm{x}$ \\
- & - & $1 / 30(3)$ & $0 / 27(0)$ & 1.000 & $\mathrm{x}$ \\
\hline
\end{tabular}

ATPase6-ND1; $\mathrm{P}<0.0011$ was considered to indicate a statistically significant difference

\begin{tabular}{|c|c|c|c|c|c|c|}
\hline 8557 & $\mathrm{G} \rightarrow \mathrm{A}$ & $\mathrm{Ala} \rightarrow \mathrm{Thr}$ & $1 / 30(3)$ & $0 / 27(0)$ & 1.000 & $\mathrm{X}$ \\
\hline 8573 & $\mathrm{G} \rightarrow \mathrm{A}$ & Gly $\rightarrow$ Asp & $1 / 30(3)$ & $0 / 27(0)$ & 1.000 & $\mathrm{X}$ \\
\hline 8584 & $\mathrm{G} \rightarrow \mathrm{A}$ & $\mathrm{Ala} \rightarrow \mathrm{Thr}$ & $1 / 30(3)$ & $1 / 27(4)$ & 1.000 & $\mathrm{X}$ \\
\hline 8684 & $\mathrm{C} \rightarrow \mathrm{T}$ & $\mathrm{Thr} \rightarrow$ Ile & $2 / 30(7)$ & $1 / 27(4)$ & 1.000 & $\mathrm{X}$ \\
\hline 8697 & $\mathrm{G} \rightarrow \mathrm{A}$ & Silent & $8 / 30(27)$ & $2 / 27(7)$ & 0.083 & $\mathrm{x}$ \\
\hline 8701 & $\mathrm{~A} \rightarrow \mathrm{G}$ & $\mathrm{Thr} \rightarrow$ Ala & $2 / 30(7)$ & $1 / 27(4)$ & 1.000 & $\mathrm{X}$ \\
\hline 8730 & $\mathrm{~A} \rightarrow \mathrm{G}$ & Silent & $1 / 30(3)$ & $0 / 27(0)$ & 1.000 & $\mathrm{x}$ \\
\hline 8742 & $\mathrm{~A} \rightarrow \mathrm{G}$ & Silent & $1 / 30(3)$ & $0 / 27(0)$ & 1.000 & $\mathrm{X}$ \\
\hline 8950 & $\mathrm{G} \rightarrow \mathrm{A}$ & $\mathrm{Val} \rightarrow \mathrm{Ile}$ & $1 / 30(3)$ & $1 / 27(4)$ & 1.000 & $\mathrm{X}$ \\
\hline 9055 & $\mathrm{G} \rightarrow \mathrm{A}$ & $\mathrm{Ala} \rightarrow \mathrm{Thr}$ & $6 / 30(20)$ & $1 / 27(4)$ & 0.105 & $\mathrm{X}$ \\
\hline
\end{tabular}

Cytb-ND1; $\mathrm{P}<0.0006$ was considered to indicate a statistically significant difference

\begin{tabular}{|c|c|c|c|c|c|c|}
\hline 14783 & $\mathrm{~T} \rightarrow \mathrm{C}$ & $\mathrm{Leu} \rightarrow \mathrm{Ile}$ & $2 / 30(7)$ & $1 / 27(4)$ & 1.000 & $\mathrm{x}$ \\
\hline 14798 & $\mathrm{~T} \rightarrow \mathrm{C}$ & Phe $\rightarrow$ Leu & $7 / 30(23)$ & 3/27 (11) & 0.304 & $\mathrm{x}$ \\
\hline 14905 & $\mathrm{G} \rightarrow \mathrm{A}$ & Silent & $8 / 30(27)$ & $2 / 27(7)$ & 0.083 & $\mathrm{x}$ \\
\hline 15043 & $\mathrm{G} \rightarrow \mathrm{A}$ & Silent & 4/30 (13) & $2 / 27(7)$ & 0.673 & $\mathrm{X}$ \\
\hline 15218 & $\mathrm{~A} \rightarrow \mathrm{G}$ & $\mathrm{Thr} \rightarrow$ Ala & $2 / 30(7)$ & $1 / 27(4)$ & 1.000 & $\mathrm{x}$ \\
\hline 15301 & $\mathrm{G} \rightarrow \mathrm{A}$ & Silent & $2 / 30(7)$ & $1 / 27(4)$ & 1.000 & $\mathrm{X}$ \\
\hline 15452 & $\mathrm{C} \rightarrow \mathrm{A}$ & $\mathrm{Leu} \rightarrow \mathrm{Ile}$ & $12 / 30(40)$ & 6/27 (22) & 0.149 & $\mathrm{x}$ \\
\hline 15454 & $\mathrm{~T} \rightarrow \mathrm{C}$ & Silent & $1 / 30(3)$ & $1 / 27$ (4) & 1.000 & $\mathrm{x}$ \\
\hline 15498 & $\mathrm{G} \rightarrow \mathrm{A}$ & Gly $\rightarrow$ Asp & $3 / 30(10)$ & $0 / 27(0)$ & 0.239 & $\mathrm{X}$ \\
\hline 15607 & $\mathrm{~A} \rightarrow \mathrm{G}$ & Silent & $8 / 30(27)$ & $1 / 27(4)$ & 0.029 & $\mathrm{x}$ \\
\hline 15622 & $\mathrm{~T} \rightarrow \mathrm{C}$ & Silent & $1 / 30(3)$ & $0 / 27(0)$ & 1.000 & $\mathrm{x}$ \\
\hline 15654 & $\mathrm{~T} \rightarrow \mathrm{C}$ & Met $\rightarrow$ Thr & $1 / 30(3)$ & $0 / 27(0)$ & 1.000 & $\mathrm{X}$ \\
\hline 15783 & $\mathrm{~T} \rightarrow \mathrm{C}$ & Silent & $1 / 30(3)$ & $0 / 27(0)$ & 1.000 & $\mathrm{x}$ \\
\hline
\end{tabular}

$N D 1 ; \mathrm{P}<0.0013$ was considered to indicate a statistically significant difference

\begin{tabular}{|c|c|c|c|c|c|c|}
\hline 3480 & $\mathrm{~A} \rightarrow \mathrm{G}$ & Silent & $6 / 30(20)$ & $1 / 27(4)$ & 0.105 & $\mathrm{x}$ \\
\hline 3507 & $\mathrm{C} \rightarrow \mathrm{T}$ & Silent & $2 / 30(7)$ & $0 / 27(0)$ & 0.492 & $\mathrm{x}$ \\
\hline 3546 & $\mathrm{C} \rightarrow \mathrm{A}$ & Silent & $1 / 30(3)$ & $0 / 27(0)$ & 1.000 & $\mathrm{x}$ \\
\hline 3703 & $\mathrm{C} \rightarrow \mathrm{T}$ & Leu $\rightarrow$ Trp & $2 / 30(7)$ & $0 / 27(0)$ & 0.492 & $\mathrm{x}$ \\
\hline 3741 & $\mathrm{C} \rightarrow \mathrm{T}$ & Silent & $2 / 30(7)$ & $1 / 27(4)$ & 1.000 & $\mathrm{x}$ \\
\hline 3930 & $\mathrm{C} \rightarrow \mathrm{T}$ & Silent & $1 / 30(3)$ & $1 / 27(4)$ & 1.000 & $\mathrm{x}$ \\
\hline 4029 & $\mathrm{C} \rightarrow \mathrm{T}$ & Silent & $1 / 30(3)$ & $1 / 27(4)$ & 1.000 & $\mathrm{x}$ \\
\hline 4188 & $\mathrm{~A} \rightarrow \mathrm{G}$ & Silent & $2 / 30(7)$ & $1 / 27(4)$ & 1.000 & $\mathrm{x}$ \\
\hline 4216 & $\mathrm{~T} \rightarrow \mathrm{C}$ & $\mathrm{Tyr} \rightarrow \mathrm{His}$ & $10 / 30(26)$ & $5 / 27(19)$ & 0.241 & $\mathrm{x}$ \\
\hline \multicolumn{7}{|c|}{ p53 } \\
\hline 12391 & $\mathrm{C}$ del & Premature stop codon & $1 / 30(3)$ & $0 / 27(0)$ & 1.000 & Novel \\
\hline 12570 & A ins & - & $20 / 30(67)$ & $0 / 27(0)$ & $0.001^{\mathrm{a}}$ & Novel \\
\hline 12570 & $\mathrm{C} \rightarrow \mathrm{A}$ & - & $4 / 30(13)$ & $17 / 27(63)$ & $0.001^{\mathrm{a}}$ & Novel \\
\hline
\end{tabular}

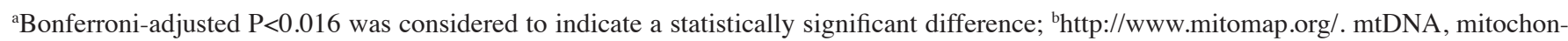
drial DNA; $N D 1$, reduced nicotinamide adenine dinucleotide dehydrogenase 1; ATPase6, adenosinetriphosphatase 6; Cytb, cytochrome $b$; del, deletion; ins, insertion. 


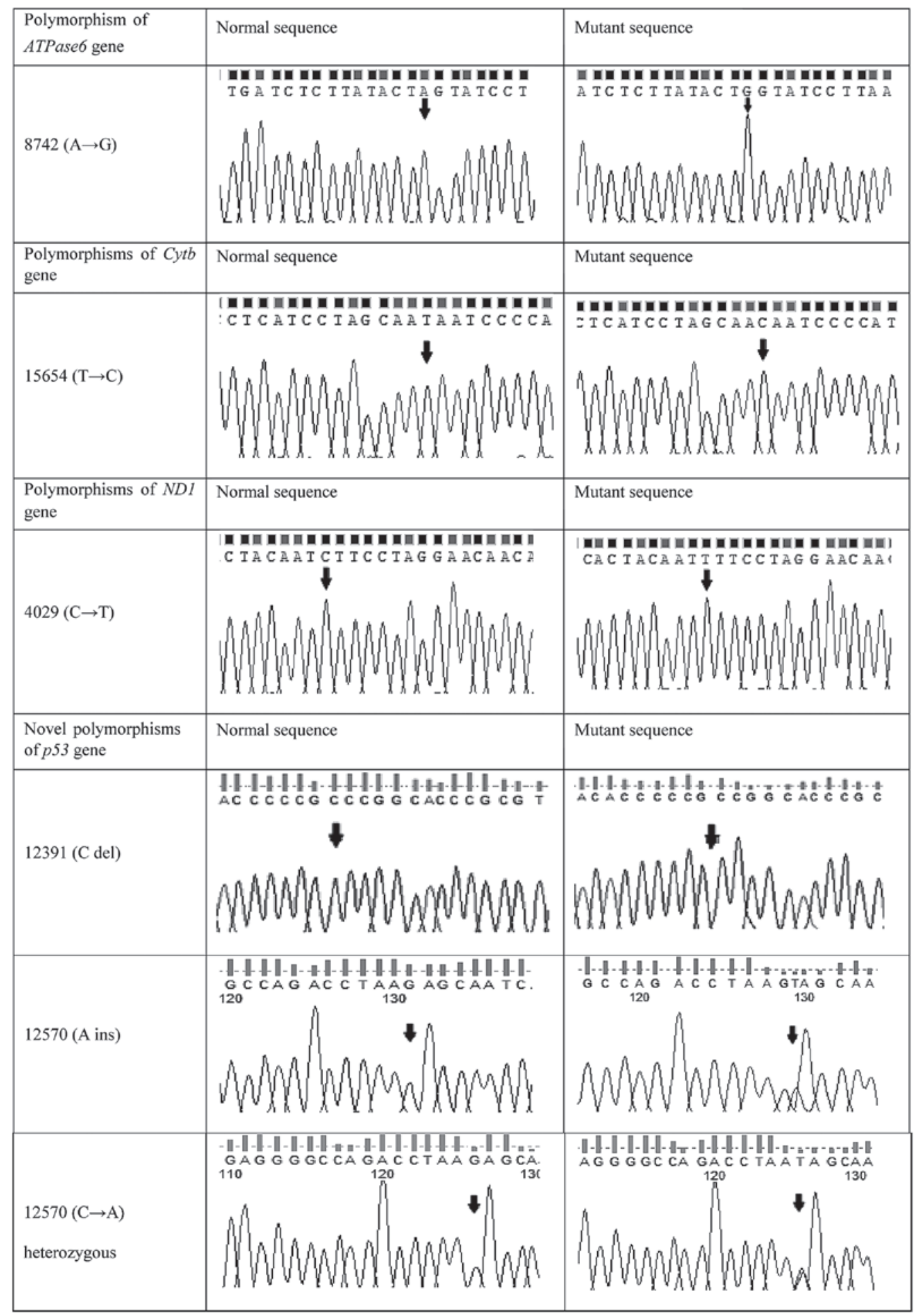

Figure 1. Representative DNA sequencing chromatograms of polymorphisms in mitochondrial DNA genes and in the $p 53$ gene. Black arrows indicate the locations of the mutations. $N D 1$, reduced nicotinamide adenine dinucleotide dehydrogenase $1 ;$ ATPase 6 , adenosinetriphosphatase 6 ; Cytb, cytochrome $b$; del, deletion; ins, insertion.

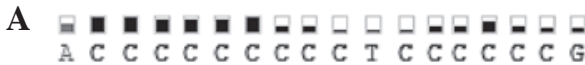

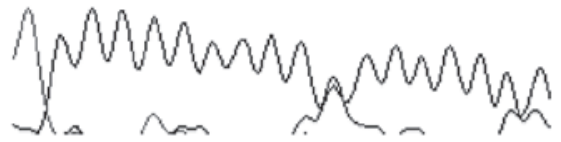

B

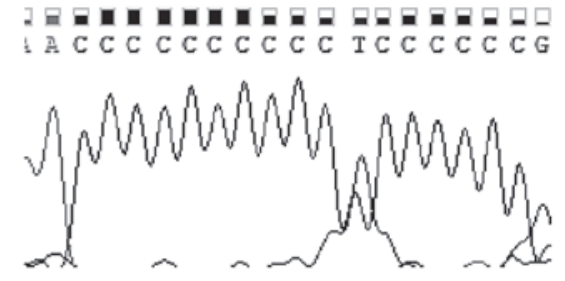

Figure 2. Representative chromatograms of D310 sequence somatic mutations. (A) 9C/10C and (B) 10C/11C heteroplasmic insertion of cytosine. 
Table IV. Numbers and percentages of mutations in different stages, grades, progression and recurrence.

\begin{tabular}{|c|c|c|c|c|c|c|c|}
\hline \multirow[b]{3}{*}{$\begin{array}{l}\text { Classification } \\
\text { of tumors }\end{array}$} & \multicolumn{7}{|c|}{ Gene mutations, n (\%) } \\
\hline & \multirow[b]{2}{*}{$\begin{array}{c}\text { ATPase6 } \\
(\mathrm{n}=22)\end{array}$} & \multirow[b]{2}{*}{$\begin{array}{c}C y t b \\
(\mathrm{n}=25)\end{array}$} & \multirow[b]{2}{*}{$\begin{array}{c}N D 1 \\
(\mathrm{n}=23)\end{array}$} & \multirow[b]{2}{*}{$\begin{array}{l}\text { D310 } \\
(n=11)\end{array}$} & \multicolumn{3}{|c|}{ p53 } \\
\hline & & & & & $\begin{array}{l}\text { A ins } \\
(n=20)\end{array}$ & $\begin{array}{c}\text { C/A het } \\
(n=4)\end{array}$ & $\begin{array}{l}C \text { del } \\
(n=1)\end{array}$ \\
\hline \multicolumn{8}{|l|}{ Stage } \\
\hline $\mathrm{Ta}(10)$ & $7(31.8)$ & $9(36.0)$ & $8(34.8)$ & $1(9.1)$ & $4(20.0)$ & $3(75.0)$ & $0(0.0)$ \\
\hline T1 (20) & $15(68.2)$ & $16(64.0)$ & $15(65.2)$ & $10(90.9)$ & $16(80.0)$ & $1(25.0)$ & $1(100.0)$ \\
\hline \multicolumn{8}{|l|}{ Grade } \\
\hline G1 (11) & $8(36.4)$ & $11(44.0)$ & $8(34.8)$ & $1(9.1)$ & $5(25.0)$ & $3(75.0)$ & $0(0.0)$ \\
\hline G2 (16) & $12(54.5)$ & $12(48.0)$ & $14(60.9)$ & $9(81.8)$ & $12(60.0)$ & $1(25.0)$ & $1(100.0)$ \\
\hline G3 (3) & $2(9.1)$ & $2(8.0)$ & $1(4.3)$ & $1(9.1)$ & $3(15.0)$ & $0(0.0)$ & $0(0.0)$ \\
\hline \multicolumn{8}{|l|}{ Progression } \\
\hline Yes (7) & $6(27.3)$ & $6(24.0)$ & $4(17.4)$ & $2(18.2)$ & $5(25.0)$ & $0(0.0)$ & $0(0.0)$ \\
\hline No $(23)$ & $16(72.7)$ & $19(76.0)$ & $19(82.6)$ & $9(81.8)$ & $15(75.0)$ & $4(100.0)$ & $1(100.0)$ \\
\hline \multicolumn{8}{|l|}{ Recurrence } \\
\hline Yes (24) & $18(81.8)$ & $20(80.0)$ & $19(82.6)$ & $8(72.7)$ & $16(80.0)$ & $3(75.0)$ & $1(100.0)$ \\
\hline No (6) & $4(18.2)$ & $5(20.0)$ & $4(17.4)$ & $3(27.3)$ & $4(20.0)$ & $1(25.0)$ & $0(0.0)$ \\
\hline
\end{tabular}

mtDNA, mitochondrial DNA; ND1, reduced nicotinamide adenine dinucleotide dehydrogenase 1; ATPase6, adenosinetriphosphatase 6; $\underline{\text { Cytb }}$. cytochrome $b$; del, deletion; ins, insertion; mt, mutant; het, heterozygous.

In the patient group, 5 different positive moderate correlations were observed between A3480G (ND1)-G9055A (ATPase6), C3741T (ND1)-C8684T (ATPase6), G8573A (ATPase6)-T15622C (Cytb), G8697A (ATPase6)-G14905A (Cytb) and A8701G (ATPase6)-T14783C (Cytb), and 1 negative moderate correlation was noticed between 12570-A insertion (p53)-C12570A heterozygous ( p53) $(\mathrm{r}>0.5, \mathrm{P}<0.05)$. Additionally, 3 different positive correlations were detected between 12570-A insertion (p53)-G8697A (ATPase6), 12570-A insertion (p53)-G14905A (Cytb) and 12570-A insertion (p53)-A15607G (Cytb) $(\mathrm{r}>0.5, \mathrm{P}<0.05)$.

\section{Discussion}

The human mitochondrial genome consists of a circular double-stranded DNA of $16,569 \mathrm{bp}$, which includes genes encoding for the electron transport chain (complexes I-IV), ATP synthase (or complex V in oxidative phosphorylation), a displacement loop (D-loop) region, 2 ribosomal RNAs (16 and 23) and 22 transfer RNAs (15). In comparison with nuclear DNA, mtDNA has a higher mutation rate, thus being more susceptible to damage, primarily due to the lack of a histone backbone, absence of an efficient repair mechanism and constant exposure to reactive oxygen species (ROS) (16). mtDNA mutations are also commonly observed in various tumors (17), both in the non-coding and in the coding regions of mtDNA in cancer cells $(12,13)$. Therefore, in the present study, mtDNA mutations were analyzed in the coding and non-coding regions of mtDNA.

The human tumour suppressor gene p53 is located in 17 p13.1, and consists of 11 exons spanning over $20 \mathrm{~kb}$ of DNA.
The open reading frame of the $p 53$ gene codes for a $53 \mathrm{kDa}$ protein (p53 protein) with 393 amino acids. The protein is involved in multiple biological functions, including cell cycle regulation, apoptosis, DNA replication and repair, and maintenance of genomic stability. Genetic changes in the p53 gene are observed in various types of human cancer (6). Previous studies on $p 53$ mutations in urinary bladder tumors have reported mutation frequencies between 6 and $61 \%(18,19)$. The majority of $p 53$ mutations are missense point mutations, and $\sim 80 \%$ are present in the evolutionarily highly conserved and functionally important exons 5-8 of the gene (20). Therefore, in the present study, $p 53$ gene mutations were analyzed in exons 5-8 and intron 5 .

The role of the tumor suppressor gene $p 53$ in bladder TCC has been extensively studied, and it is known that mutations in this gene correlate with the grade of cellular dedifferentiation, stage of local infiltration, recurrence and tumor progression $(21,22)$. Therefore, mutations in the $p 53$ gene are associated with the grade and stage of bladder cancer, and may be important in the multistep progression of bladder cancer. Lorenzo Romero et al (8) observed that mutations in p53 did not appear in healthy bladder mucosa, while they were significantly more frequent in pT1 and high-grade (grade 2 and 3) tumors. In the present study, 12570-A insertion on the p53 gene was significant in patients at $\mathrm{T} 1$ stage $(\mathrm{P}<0.05)$. In another study, 2 different mutations were identified in exon 5, 1 of which was detected on codon 153 (C>T) (6). In the present study, a novel frameshift mutation (12391-C deletion) was noticed on the same codon, which causes a premature stop codon. In addition, 2 novel mutations were identified in intron 5, of which, the 12570-A insertion mutation was only 
detected in patients (67\%). At the same location, the C12570A heterozygous mutation was significantly higher in controls $(63 \%)$ than in patients $(13 \%)(\mathrm{P}<0.05)$. Therefore, the 12570-A insertion mutation may contribute to the development of the disease, whereas the C12570A heterozygous mutation may have a protective effect in this process.

All the mitochondrial protein coding genes encode subunits of the oxidative phosphorylation enzymes that are responsible for the energy generation pathway (23). The oxidative phosphorylation system is composed of 5 complexes (I-V) that are assembled from multiple polypeptides, a number of which are encoded by mtDNA and others by nuclear DNA (24). Among the above 5 complexes, complex III is a membrane-bound enzyme that catalyzes the transfer of electrons from ubiquinol to Cytc (25). In this pathway, Cytb is fundamental for the assembly and function of complex III (11). It is known that compromised mitochondrial function due to mtDNA mutations enhances the generation of ROS. It has been widely demonstrated that ROS are also involved in numerous proliferating signaling pathways associated with tumor promotion (16). Another complex, complex $\mathrm{V}$, is important in adenosine triphosphate (ATP) production and apoptosis $(26,27)$. The contribution of mtDNA complex $\mathrm{V}$ variants in cell transformation, elevated ROS production and tumor progression has been described (28). Additionally, efficient programmed cell death requires the molecular machinery of the ATP synthase (29). The ATPase 6 gene, one of the complex V genes, contributes to mtDNA maintenance (15). Furthermore, ND1 (or complex I) has the most number of subunits encoded by mtDNA. The production of ROS probably occurs when complex I activity is interrupted (23). In addition, the majority of mutations in cancer occur in the mitochondrial D-loop region, which functions as a promoter for both the heavy and light strands of mtDNA (13). Therefore, in the present study, the mtDNA genes ATPase 6, Cytb and NDI, and the D-loop region of mtDNA, were analyzed in 30 TCC patients and 27 healthy individuals.

The various mutations frequencies were determined due to the variations in the tumor stage and grade, and a much higher number of mutations were observed in tumors of high stage and grade than in tumors of low stage and grade (2). Thus, the present study also investigated the association between gene mutations and tumor stage and grade.

The $\mathrm{A} 15607 \mathrm{G}$ polymorphism on the Cytb gene was significant in patients at $\mathrm{T} 1$ stage $(\mathrm{P}<0.05)$. A total of $34 \mathrm{mtDNA}$ mutations were identified in TCC patients, of which, 15 cause an amino acid change. The present results are consistent with a previous study by the present authors, in which mtDNA mutations were examined in TCC patients and healthy individuals. In that study, a total of 68 mutations were identified, a number of which are similar to the ones reported in the present study (30). The D-loop region, while being non-coding, has been demonstrated to have a higher mutation rate than coding mtDNA within cancer patients. Previous studies suggested that mutations in the D-loop region could alter mtDNA transcription and further lead to respiratory chain alteration, and thereby disrupt mitochondrial-induced apoptosis $(31,32)$. Therefore, mutations in the D-loop region may play an indirect role in the tumorigenic process, since this region is responsible for the control of mtDNA proliferation (16). Chang et al (13) observed that of 88 tumors with p53 mutations, 34 (38.6\%) had D-loop mutations, and its frequency was significantly higher in tumors with $p 53$ mutations than in tumors without p53 mutations $(23 / 106 ; 21.7 \%)$ (13). Although the present study identified numerous mutations in the D-loop region, no correlation was observed between mutations in the D-loop region and in the $p 53$ gene in bladder cancer patients.

Analyses of the mutational spectra for the mtDNA and $p 53$ genes may provide clues about cancer etiology, mechanisms of mutations and the role of $p 53$ and mtDNA genes in the development of urinary bladder cancer. mtDNA and $p 53$ mutations have been previously described in different tumors, whereas similar studies focusing on bladder cancer are scarce $(14,16)$. In the present study, the $p 53$ and mtDNA mutational spectra for urinary bladder tumors were analyzed by studying the mutation frequency in exons 5-8 as well as in intron 5 of the $p 53$ gene, and in the ND1, ATPase 6 and Cytb genes, in addition to the D-loop D310 region of mtDNA, in patients with TCC at various stages and grades. $p 53$ gene mutations were analyzed in patients who had mtDNA mutations, and the association between mtDNA and p53 mutations in TCC of the bladder was investigated. Achanta et al (33) demonstrated an association between the expression of cytoplasmic $p 53$ and the vulnerability of mtDNA to exogenous damage. The authors also revealed that $p 53$ has a role in maintaining mitochondrial genetic stability through its ability to translocate to mitochondria and interact with DNA polymerase $\gamma$, thus enhancing its DNA replication function, in response to mtDNA damage. In addition, the authors also noticed that loss of $p 53$ resulted in a significant increase in mtDNA vulnerability to damage, leading to increased frequency of in vivo mtDNA mutations. Gochhait et al (14) suggested that the concomitant presence of somatic alterations in mtDNA and the DNA binding domain of the $p 53$ gene facilitates cell survival and tumorigenesis. To the best of our knowledge, the present is the first study that attempts to correlate mtDNA and $p 53$ mutations in TCC. In the present study, the $\mathrm{r}$ test was used to investigate the association between mtDNA and p53 mutations in TCC of the bladder. Positive correlations were observed between 12570-A insertion ( $p 53$ mutation) and G8697A (ATPase6 mutation), G14905A and A15607G (Cytb mutation) $(\mathrm{r}>0.3, \mathrm{P}<0.05)$.

The present results, as well as the published data regarding the sequence analysis of the mutated $p 53$ gene and mtDNA, revealed that there were no consistent patterns of $p 53$ and mtDNA mutations in bladder cancer. Further studies are required to determine whether $p 53$ and mtDNA mutations could serve as an important predictor for tumor progression or as a useful marker for selection of a more suitable treatment, and to explain whether there are consistent patterns of mutation in bladder cancer. Therefore, future analyses of the progression of bladder cancer patients with mutated $p 53$ and mtDNA genes will help clarify this aspect.

\section{References}

1. Jemal A, Bray F, Center MM, Ferlay J, Ward E and Forman D: Global Cancer Statistics. CA Cancer J Clin 61: 69-90, 2011.

2. Fujimoto K, Yamada Y, Okajima E, Kakizoe T, Sasaki H, Sugimura T and Terada M: Frequent association of p53 gene mutation in invasive bladder cancer. Cancer Res 52: 1393-1398, 1992. 
3. Kiriluk KJ, Prasad SM, Patel AR, Steinberg GD and Smith ND Bladder cancer risk from occupational and environmental exposures. Urol Oncol 30: 199-211, 2012.

4. Williams SG and Stein JP: Molecular pathways in bladder cancer. Urol Res 32: 373-385, 2004.

5. Lin HY, Huang $\mathrm{CH}, \mathrm{Wu}$ WJ, Chou YH, Fan PL and Lung FW: Mutation of the p53 tumor suppressor gene in transitional cel carcinoma of the urinary tract in Taiwan. Kaohsiung $\mathbf{J}$ Med Sci 21: 57-64, 2005

6. Berggren P, Steineck G, Adolfsson J, Hansson J, Jansson O, Larsson P, Sandstedt B, Wijkström H and Hemminki K: p53 mutations in urinary bladder cancer. Br J Cancer 84: 1505-1511, 2001.

7. Greenblatt MS, Bennett WP,Hollstein M and Harris CC: Mutations in the p53 tumor suppressor gene: Clues to cancer etiology and molecular pathogenesis. Cancer Res 54: 4855-4878, 1994.

8. Lorenzo Romero JG, Salinas Sánchez AS, Giménez Bachs JM Sánchez Sánchez F, Escribano Martínez J, Hernández Millán IR, Segura Martín M and Virseda Rodríguez JA: p53 Gene mutations in superficial bladder cancer. Urol Int 73: 212-218, 2004.

9. Chen GF, Chan FL, Hong BF, Chan LW and Chan PS: Mitochondrial DNA mutations in chemical carcinogen-induced rat bladder and human bladder cancer. Oncol Rep 12: 463-472, 2004

10. Wada T, Tanji N, Ozawa A, Wang J, Shimamoto K, Sakayama K and Yokoyama M: Mitochondrial DNA mutations and 8-hydroxy-2'-deoxyguanosine Content in Japanese patients with urinary bladder and renal cancers. Anticancer Res 26 3403-3408, 2006.

11. Dasgupta S, Hoque MO, Upadhyay S and Sidransky D: Mitochondrial cytochrome B gene mutation promotes tumor growth in bladder cancer. Cancer Res 68: 700-706, 2008.

12. Carew JS and Huang P: Mitochondrial defects in cancer. Mol Cancer 1: 9, 2002.

13. Chang SC, Lin PC, Yang SH, Wang HS, Liang WY and Lin JK Mitochondrial D-loop mutation is a common event in colorectal cancers with p53 mutations. Int J Colorectal Dis 24: 623-628, 2009

14. Gochhait S, Bhatt A, Sharma S, Singh YP, Gupta P and Bamezai RN: Concomitant presence of mutations in mitochondrial genome and p53 in cancer development-a study in north Indian sporadic breast and esophageal cancer patients. Int J Cancer 123: 2580-2586, 2008.

15. Ghaffarpour M, Mahdian R, Fereidooni F, Kamalidehghan B, Moazami N and Houshmand M: The mitochondrial ATPase6 gene is more susceptible to mutation than the ATPase8 gene in breast cancer patients. Cancer Cell Int 14: 21, 2014.

16. Prior SL, Griffiths AP and Lewis PD: A study of mitochondrial DNA D-loop mutations and p53 status in nonmelanoma skin cancer. Br J Dermatol 161: 1067-1071, 2009.

17. Zhou S, KAchap S and Singh KK: Mitochondrial impairment in p53-deficient human cancer cells. Mutagenesis 18: 287-292, 2003.

18. Shipman R, Schraml P, Moch H, Colombi M, Sauter G, Mihatsch $\mathrm{M}$ and Ludwig C: p53 protein accumulation and p53 gene alterations (RFLP, VNTR and p53 gene mutations) in non-invasive versus invasive human transitional bladder cancer. Int J Oncol 10: 801-806, 1997.
19. Sidransky D, Von Eschenbach A, Tsai YC, Jones P, Summerhayes I, Marshall F, Paul M, Green P, Hamilton SR, Frost $\mathrm{P}$, et al: Identification of p53 gene mutations in bladder cancers and urine samples. Science 252: 706-709, 1991.

20. Phillips HA, Howard GC and Miller WR: p53 mutations as a marker of malignancy in bladder washing samples from patients with bladder cancer. Br J Cancer 82: 136-141, 2000.

21. Álvarez Kindelán J, López-Beltrán A and Requena Tapia MJ: Molecular biology in bladder cancer. Actas Urol Esp 24: 604-625, 2000 (In Spanish).

22. Lianes P: Biología Molecular del Cáncer de Vejiga. In: Tumores Vesicales Superficiales. Vicente J, Chéchile G and Salvador J (eds). Acción Médica, Madrid,pp47-60, 2000 (In Spanish).

23. Akouchekian M, Houshmand M, Akbari MH, Kamalidehghan B and Dehghan M: Analysis of mitochondrial ND1 gene in human colorectal cancer. J Res Med Sci 16: 50-55, 2011.

24. Petros JA, Baumann AK, Ruiz-Pesini E, Amin MB, Sun CQ, Hall J, Lim S, Issa MM, Flanders WD, Hosseini SH, et al: mtDNA mutations increase tumorigenicity in prostate cancer. Proc Natl Acad Sci USA 102: 719-724, 2005.

25. Blakely EL, Mitchell AL, Fisher N, Meunier B, Nijtmans LG, Schaefer AM, Jackson MJ, Turnbull DM and Taylor RW: A mitochondrial Cytochrome $b$ mutation causing severe respiratory chain enzyme deficiency in human and yeast. FEBS J 272: 3583-3592, 2005 .

26. Jonckheere AI1, Smeitink JA and Rodenburg RJ: Mitochondrial ATP synthase: architecture, function and pathology. J Inherit Metab Dis 35: 211-225, 2012

27. Czarnecka AM, Kukwa W, Krawczyk T, Scinska A, Kukwa A and Cappello F: Mitochondrial DNA mutations in cancer - from bench to bedside. Front Biosci (Landmark Ed) 15: 437-460, 2010

28. Amuthan G, Biswas G, Zhang SY, Klein-Szanto A, Vijayasarathy $\mathrm{C}$ and Avadhani NG: Mitochondria-to-nucleus stress signaling induces phenotypic changes, tumor progression and cell invasion. Embo J 20: 1910-1920, 2001

29. Matsuyama S, Xu Q, Velours J and Reed JC: The Mitochondrial F0F1-ATPase proton pump is required for function of the proapoptotic protein Bax in yeast and mammalian cells. Mol Cell 1: 327-336, 1998

30. Guney AI, Ergec DS, Tavukcu HH, Koc G, Kirac D, Ulucan K, Javadova D and Turkeri L: Detection of mitochondrial DNA mutations in nonmuscle invasive bladder cancer. Genet Test Mol Biomarkers 16: 672-678, 2012.

31. Simonnet H, Alazard N,Pfeiffer K, Gallou C, Béroud C, Demont J, Bouvier R, Schägger $\mathrm{H}$ and Godinot $\mathrm{C}$ : Low mitochondrial respiratory chain content correlates with tumor aggressiveness in renal cell carcinoma. Carcinogenesis 23: 759-768, 2002.

32. Meierhofer D, Mayr JA, Foetschl U, Berger A, Fink K, Schmeller N, Hacker GW, Hauser-Kronberger C, Kofler B and Sperl W: Decrease of mitochondrial DNA content and energy metabolism in renal cell carcinoma. Carcinogenesis 25: 1005-1010, 2004

33. Achanta G, Sasaki R, Feng L, Carew JS, Lu W, Pelicano H, Keating MJ and Huang P: Novel role of p53 in maintaining mitochondrial genetic stability through interaction with DNA Pol gamma. EMBO J 24: 3482-3492, 2005. 